ГАЛУЗЕВИЙ АСПЕКТ РОЗВИТКУ НАЦІОНАЛЬНОГО ГОСПОДАРСТВА

УДК 331.1

DOI: $10.25140 / 2411-5215-2019-4(20)-119-126$

Максим Забаштанський, Андрій Роговий, Світлана Шульга

\title{
СУЧАСНІ ПІДХОДИ ДО УПРАВЛІННЯ ПЕРСОНАЛОМ ПІДПРИЕМСТВ БУДІВЕЛЬНОЇ ГАЛУЗІ
}

Максим Забаштанский, Андрей Роговой, Светлана Шульга

\section{СОВРЕМЕННЫЕ ПОДХОДЫ К УПРАВЛЕНИЮ ПЕРСОНАЛОМ ПРЕДПРИЯТИЙ СТРОИТЕЛЬНОЙ ОТРАСЛИ}

\author{
Maksym Zabashtanskyi, Andrii Rogovyi, Svitlana Shulha \\ MODERN APPROACHES OF MANAGEMENT BY PERSONNEL \\ OF BUILDING ENTERPRISES
}

У статті досліджено сучасні підходи до управління персоналом на підприємствах будівельної галузі, з'ясовано їхній вплив на забезпечення результативності та безперебійності ї̈ функціонування. Встановлено безпосередній взаємозв'язок між станом начіональної економіки, рівнем життя суспільства та динамічністю прочесу оновлення житлового фонду в країні. Обтрунтовано необхідність зміни наявних підходів до управління персоналом на підприємствах будівельної галузі в частині трансформації складових ї̈ матеріального та нематеріального стимулювання. Визначено головні перешкоди ефективному функиіонуванню будівельної галузі та сформовано перелік заходів їх нівелювання. Запропоновано етапи розроблення кадрової політики суб'єктів господарювання будівельної галузі. Надано пропозицї шедо підвищення ефективності управління персоналом на підприємствах будівельної галузі шляхом удосконалення їхньої кадрової політики.

Ключові слова: управління персоналом; кадрова політика; будівельна галузь; мотивація персоналу; політика управління персоналом.

Рис.: 1. Табл.: 5. Бібл.: 7.

В статье исследованы современные подходы к управлению персоналом на предприятиях строительной отрасли, выяснено их влияние на обеспечение результативности и бесперебойности ее функиионирования. Установлено непосредственную взаимосвязь между состоянием начиональной экономики, уровнем жизни общества и динамичностью прочесса обновления жилищного фонда в стране. Обоснована необходимость изменения существующих подходов к управлению персоналом на предприятиях строительной отрасли в части трансформачии составляющих ее материального и нематериального стимулирования. Определены главные препятствия эффективному функчионированию строительной отрасли и сформирован перечень мероприятий их нивелирования. Предложены этапь разработки кадровой политики субъектов хозяйствования строительной отрасли. Сформированы предложения по повышению эффективности управления персоналом на предприятиях строительной отрасли путем совершенствования их кадровой политики.

Ключевые слова: управление персоналом; кадровая политика; строительная отрасль; мотивация персонала; политика управления персоналом.

Рис.: 1. Табл.: 5. Библ.: 7.

In the article the modern approaches to personnel management at the enterprises of the building industry are investigated, their influence on maintenance of efficiency and uninterrupted functioning of it is determined. A direct relationship was established between the state of the national economy, the level of society and the dynamism of the process of renovation of the housing stock in the country. The necessity of changing existing approaches to personnel management at the enterprises of the building industry is grounded in the part of the transformation of the components of its material and immaterial stimulation. The main obstacles to the effective functioning of the construction industry are determined and the list of measures for their leveling is formed. The proposed stages of the development of personnel policy of the subjects of management of the construction industry. Provided suggestions on improving the efficiency of personnel management at the enterprises of the construction industry by improving their personnel policy.

Keywords: personnel management; personnel policy; construction industry; motivation of staff; HR policy.

Fig.: 1. Table: 5. References: 7.

JEL Classification: E24; M12

Постановка проблеми. Будівельна галузь посідає одне з найбільш важливих місць у функціонуванні та розвитку національної економіки. Її головним завданням є створення необхідних умов життєзабезпечення населення, а також формування базису діяльності реального сектору економіки. Проте зростання попиту на кваліфіковану робочу силу протягом останніх років суттєво загострює питання формування ефективної кадрової політики, спрямованої на задоволення потреб персоналу та забезпечення ефективності функціонування суб'єктів господарювання будівельної галузі. Однією з ключо-

() Забаштанський М. М., Роговий А. В., Шульга С. С., 2019 
ГАЛУЗЕВИЙ АСПЕКТ РОЗВИТКУ НАЦІОНАЛЬНОГО ГОСПОДАРСТВА

вих перешкод розвитку сучасних будівельних підприємств $є$ неефективно побудована кадрова політика, яка стримує розвиток галузі на національному рівні. Ці проблеми $є$ досить важливими та потребують раціонального вирішення.

Аналіз останніх досліджень і публікацій. Проблеми управління персоналом досліджували багато вітчизняних і закордонних науковців, зокрема: Н. І. Барановська, М. Вебер, Ф. Гільберт, М. К. Казакова， А. Маслоу， Г. В. Назарова， М. Портер， Р. В. Севастьянов, Ф. Тейлор, А. Файоль, А. В. Холодницька, Ю. К. Чернова. Проте, незважаючи на існування проведених досліджень, деякі аспекти в управлінні персоналом суб'єктів господарювання будівельної сфери потребують подальшого поглибленого вивчення.

Виділення недосліджених частин загальної проблеми. У сучасних умовах євроекономічної інтеграції, значного попиту на вітчизняну робочу силу за кордоном дедалі більшого значення у функціонуванні будь-якої галузі, суб'єкта господарювання набуває наявність висококваліфікованого персоналу, здатного забезпечити реалізацію процесів розширеного відтворення. Особливо проблема управління персоналом загострюється серед суб'єктів господарювання будівельної галузі як однієї з провідних галузей національної економіки. У процесі дослідження питання управління персоналом значна когорта науковців та практиків розглядають особливості швидкого пошуку персоналу, оптимізації рівня оплати праці, проте не всі з них вирішують це питання в контексті забезпечення їхнього професійного зростання та розвитку. Плинність кадрів у галузі будівництва нині залишається однією з найбільших проблем, що спонукає до подальшого напрацювання підходів щодо ефективного управління персоналом.

Метою статті. Головною метою цієї статті є аналіз та оцінка сучасних підходів управління персоналом підприємств будівельної галузі й розробка рекомендацій щодо підвищення ефективності кадрової політики з метою забезпечення їх результативного функціонування.

Виклад основного матеріалу. Будівельна галузь $є$ однією 3 провідних галузей національної економіки, від стану якої залежить ефективність функціонування всіх інших систем господарювання в країні. Значення функціонування цієї галузі для економіки країни $є$ надзвичайно вагомим, оскільки вона забезпечує інфраструктурний розвиток національної економіки, створює значну кількість робочих місць і споживає продукцію багатьох інших галузей національної економіки, серед яких можна виділити такі: виробництво будівельних матеріалів і відповідного обладнання, машинобудівна галузь, металургія та металообробка, нафтохімія, виробництво скла, деревообробна і фарфорофаянсова промисловість, транспорт, енергетика тощо [6]. Однак головною особливістю будівельної галузі є те, що вона формує базис розвитку національної економіки, сприяє реалізації функції життєзабезпечення суспільства.

Забезпечення результативності та зростання обсягів робіт будівельної галузі виступає своєрідним індикатором фази розвитку національної економіки, а також сприяє підвищенню добробуту населення. Але, на жаль, сучасний фінансовий та технічний стан будівельної галузі в України порівняно з іншими країнами перебуває на недостатньому рівні, що зумовлено низькою платоспроможністю населення, недостатньою результативністю функціонування переважної більшості вітчизняних суб'єктів господарювання, низьким рівнем запровадження інноваційних технологій у будівництві.

Нині вітчизняний житловий фонд характеризується значними обсягами фізичного та морального зносу. Так, до 80 \% житла належать до такого, яке побудоване за застарілими нормами, що характеризується значними енергетичними витратами [3]. Разом 3 тим значна частина житлових будівель на сьогодні не обладнана всіма необхідними умовами для нормального життя населення (табл. 1). 
ГАЛУЗЕВИЙ АСПЕКТ РОЗВИТКУ НАЦІОНАЛЬНОГО ГОСПОДАРСТВА

Таблиця 1

Обладнання квартир у житлових будинках та нежитлових будівлях міського та сільського населення станом на 1 січня 2018 року

\begin{tabular}{|l|c|c|c|}
\hline \multirow{2}{*}{ Категорія обладнання } & \multicolumn{3}{|c|}{ Питома вага обладнаних будівель, \% } \\
\cline { 2 - 4 } & усього & міська місцевість & сільська місцевість \\
\hline Водопровід & 60,9 & 77,3 & 31,5 \\
\hline Гаряче водопостачання & 47,1 & 62,8 & 19,1 \\
\hline Каналізація & 58,9 & 76,4 & 27,7 \\
\hline Опалення & & & 1,2 \\
\hline центральне & 47,1 & 73,0 & 49,5 \\
\hline від індивідуальних установок & 21,2 & 5,3 & 5,2 \\
\hline пічне & 16,4 & 0,7 & 53,8 \\
\hline Газ & & & 30,3 \\
\hline природний & 74,1 & 85,5 & \\
\hline скраплений & 11,0 & 0,1 & \\
\hline
\end{tabular}

Джерело: складено за даними Державної служби статистики України [2].

За даними, наведеними в табл. 1, можна простежити, що лише 60,9 \% житлового фонду населення обладнано водопроводом, 3 них гарячим водопостачанням лише 47,1 \%. Більша частина не обладнаного або частково обладнаного житлового фонду перебуває саме в користуванні сільського населення, з яких 31,5 \% обладнані водопроводом і лише 19,1 \% мають гарячу воду. Майже половина населення $(47,1$ \%) має центральне опалення, проте це стосується міського населення, у сільській місцевості переважає індивідуальне та пічне опалення, питома вага якого становить 49,5 і 44,2 \% відповідно. Така статистика стану житлового фонду засвідчує, що переважна частина населення не має всіх необхідних умов для відповідного життєзабезпечення, що вимагає суттєвого прискорення процесів його оновлення, які нині, на жаль, мають зворотну динаміку (табл. 2).

Таблиця 2

Динаміка обсягу житлового фонду за 2010-2017 рр., млн м²

\begin{tabular}{|c|c|c|}
\hline Рік & Загальна площа житлових приміщень & Порівняно 3 2017 роком, \% \\
\hline 2010 & 1079,5 & 109,8 \\
\hline 2012 & 1094,2 & 111,3 \\
\hline 2013 & 1096,5 & 111,5 \\
\hline 2014 & 966,1 & 98,2 \\
\hline 2015 & 973,7 & 99,0 \\
\hline 2016 & 974,5 & 99,1 \\
\hline 2017 & 983,4 & - \\
\hline
\end{tabular}

Джерело: складено за даними Державної служби статистики України [2].

Проаналізувавши наведену динаміку руху житлового фонду, можна побачити, що наявна стійка тенденція до поступового зменшення його обсягу за останні роки. Найбільше скорочення обсягів житлового фонду відбулось у 2014 році, коли загальна площа житлового фонду, якщо порівняти 32013 роком, зменшилась на 13,3 \%, або на 130,4 млн м². Протягом аналізованого періоду фактичний обсяг скорочення житлового фонду становить 96,1 млн м².

Водночас, незважаючи на зростаючу потребу в оновленні вітчизняного житлового фонду, чисельність суб'єктів господарювання, зайнятих у будівельній сфері, поступово скорочується (табл. 3). 
ГАЛУЗЕВИЙ АСПЕКТ РОЗВИТКУ НАЦІОНАЛЬНОГО ГОСПОДАРСТВА

Таблиця 3

Динаміка кількості суб' єктів господарювання та чисельності зайнятих у будівельній галузі Украӥни протягом 2010-2017 рр.

\begin{tabular}{|c|c|c|c|c|c|c|c|c|}
\hline \multirow{2}{*}{ Показник } & \multicolumn{9}{|c|}{ Piк } \\
\cline { 2 - 9 } & $\mathbf{2 0 1 0}$ & $\mathbf{2 0 1 1}$ & $\mathbf{2 0 1 2}$ & $\mathbf{2 0 1 3}$ & $\mathbf{2 0 1 4}$ & $\mathbf{2 0 1 5}$ & $\mathbf{2 0 1 6}$ & $\mathbf{2 0 1 7}$ \\
\hline Кількість підприємств, од. & 38215 & 37544 & 34077 & 36185 & 29785 & 29165 & 24333 & 27468 \\
\hline Темп приросту до 2010 року, \% & 100,0 & 98,24 & 89,17 & 94,69 & 77,94 & 76,32 & 63,67 & 71,88 \\
\hline Кількість зайнятих працівників, тис. осіб & 472,1 & 432,7 & 411,1 & 371,7 & 286,1 & 248,1 & 247,0 & 257,8 \\
\hline Темп приросту до 2010 року, \% & 91,65 & 87,08 & 78,73 & 60,60 & 52,55 & 52,32 & 54,61 & 91,65 \\
\hline
\end{tabular}

Джерело: складено за даними Державної служби статистики України [2].

Дані, наведені в табл. 3, підтверджують те, що кількість підприємств, задіяних у сфері будівництва, за 2010-2017 роки зменшилась на 28\%, поряд з цим відбувається скорочення чисельності працівників, зайнятих у цій сфері, на 45 \%. Зазначена тенденція має безпосередній зв'язок із результативністю їх функціонування, а також станом національної економіки. Скорочення чисельності суб'єктів господарювання та працівників, зайнятих у сфері будівництва, певною мірою зумовлено відсутністю платоспроможного попиту на новостворені житлові об'єкти, зумовленого низьким рівнем доходів населення, а також відсутності відповідної державної підтримки фінансового забезпечення необхідних програм житлового будівництва. Сукупність вищеперерахованих факторів призвела до значного погіршення результативності функціонування суб'єктів господарювання зазначеної галузі, динаміка якої наведена в табл. 4.

Таблиця 4

Динаміка результативності функиіонування суб'єктів господарювання будівельної галузі за 2010-2017 рр.

\begin{tabular}{|c|c|c|c|c|c|}
\hline \multirow{2}{*}{ Рік } & \multirow{2}{*}{$\begin{array}{c}\text { Фінансовий } \\
\text { результат } \\
\text { (сальдо), } \\
\text { млн грн }\end{array}$} & \multicolumn{2}{|c|}{$\begin{array}{c}\text { Підприємства, які } \\
\text { одержали прибуток }\end{array}$} & \multicolumn{2}{|c|}{$\begin{array}{c}\text { Підприсмства, які } \\
\text { одержали збиток }\end{array}$} \\
\cline { 3 - 6 } & $\begin{array}{c}\text { у до загальної } \\
\text { підькості }\end{array}$ & $\begin{array}{c}\text { фінансовий } \\
\text { результат, } \\
\text { млн грн }\end{array}$ & $\begin{array}{c}\text { у \% до загальної } \\
\text { кількості } \\
\text { підприємств }\end{array}$ & $\begin{array}{c}\text { фінансовий } \\
\text { результат, } \\
\text { млн грн }\end{array}$ \\
\hline 2010 & $-5095,7$ & 53,9 & 4358,7 & 46,1 & 9454,4 \\
\hline 2011 & $-4580,1$ & 58,8 & 4724,9 & 41,2 & 9305,0 \\
\hline 2012 & $-1012,7$ & 58,9 & 8367,0 & 41,1 & 9379,7 \\
\hline 2013 & $-5893,2$ & 61,4 & 5317,1 & 38,6 & 31210,3 \\
\hline 2014 & $-27948,8$ & 61,9 & 5693,7 & 38,1 & 30739,3 \\
\hline 2015 & $-25861,9$ & 70,8 & 4877,4 & 29,2 & 17902,7 \\
\hline 2016 & $-10553,0$ & 70,4 & 7349,7 & 29,6 & 13940,2 \\
\hline 2017 & $-5014,3$ & 71,0 & 8925,9 & 29,0 & \\
\hline
\end{tabular}

Джерело: складено за даними Державної служби статистики України [2].

3 даних табл. 4 випливає, що протягом останніх років будівельна галузь функціонує зі збитками. Найбільший обсяг збитків припадає саме на 2014-2015 рр., що поряд із вищезазначеними факторами зумовлено значною девальвацією національної грошової одиниці та збільшенням рівня інфляції в країні. У 2017 році обсяг отриманих збитків суб'єктами господарювання будівельної галузі зменшився до 5014,3 млн грн, проте відсоток підприємств галузі, які працювали зі збитками, навпаки зріс до 71 \%. Сукупність вищезазначених факторів генерують накопичення фізичного та морального зносу в галузі, спричиняють скорочення кваліфікованого персоналу, що вимагає перегляду кадрової політики.

Процес адаптації кадрової політики до наявних у будівельній сфері викликів та загроз, на перший погляд, може здатися не досить важливим, адже чисельність фахівців будівельного профілю різної кваліфікації та рівня освіти досить велика, і здається, що 
ГАЛУЗЕВИЙ АСПЕКТ РОЗВИТКУ НАЦІОНАЛЬНОГО ГОСПОДАРСТВА

добір потрібної команди для певних проєктів не викликатиме труднощів. Але на справді ця проблема набуває дедалі більших обертів. Робота у сфері будівництва вимагає значного практичного досвіду, що несе за собою відповідальність за виконану роботу. Більшість робітників, які почали роботу в цій сфері, не в змозі виконати повний обсяг роботи через недостатній рівень кваліфікації. Деякі компанії не намагаються вирішувати цю проблему шляхом навчання, а просто залучають більш досвідчених та кваліфікованих працівників, які чітко усвідомлюють своє місце й роль у структурі виробничого процесу. Саме тому більшість робітників залишають роботу у сфері будівництві та шукають себе в іншій галузі. Крім того, значна різниця в заробітній платі будівельників в Україні та за їі межами стає причиною значної міграції трудових ресурсів. Динаміка витрат на персонал суб'єктів господарювання будівельної галузі за 2013-2017 роки відображена в табл. 5.

Таблиця 5

Витрати на персонал суб' єктів господарювання будівельної галузі протягом 2013-2017 рр., млн грн

\begin{tabular}{|c|c|c|c|c|c|}
\hline \multirow{2}{*}{ Роки } & \multirow{2}{*}{$\begin{array}{c}\text { Витрати на } \\
\text { персонал }\end{array}$} & \multicolumn{2}{|c|}{ У тому числі } & \multicolumn{2}{c|}{$\begin{array}{c}\text { Сума витрат на персонал } \\
\text { за всіма галузями }\end{array}$} \\
\cline { 3 - 6 } & & $\begin{array}{c}\text { витрати на опла- } \\
\text { ту праці }\end{array}$ & $\begin{array}{c}\text { відрахування на } \\
\text { соціальні заходи }\end{array}$ & усього & $\begin{array}{c}\text { 3 них витрати на } \\
\text { оплату праці }\end{array}$ \\
\hline 2013 & 13938,7 & 10196,8 & 3741,9 & 425164,3 & 312874,3 \\
\hline 2014 & 15433,3 & 11266,1 & 4167,2 & 401460,6 & 296437,0 \\
\hline 2015 & 11870,4 & 8801,7 & 3068,7 & 432096,6 & 325512,8 \\
\hline 2016 & 12933,0 & 10635,0 & 2298,0 & 477294,0 & 394312,1 \\
\hline 2017 & 18543,9 & 15199,3 & 3344,6 & 620357,3 & 512426,9 \\
\hline
\end{tabular}

Джерело: [2].

Динаміка наведених витрат на персонал суб'єктів господарювання будівельної галузі показує позитивну тенденцію до їх зростання. Проте, якщо врахувати інфляційні коливання, а також втрату купівельної спроможності національної грошової одиниці протягом останніх років, можна констатувати скорочення обсягу реальних доходів працівників, задіяних у цій галузі.

Однак необхідно звернути увагу на те, що питома вага витрат на персонал суб'єктів господарювання будівельної галузі в загальних витратах по всіх галузях становить лише 2,9\%, що є надзвичайно низьким показником з огляду на важливість будівельної галузі для функціонування національної економіки. Певною мірою така ситуація може бути зумовлена не офіційним працевлаштуванням робітників будівельної галузі, а також небажанням роботодавців сплачувати в повному обсязі обов'язкові платежі, нести відповідальність за своїх працівників.

Значна частина працівників, які працюють на будівництві, не є офіційно зареєстрованими, а працюють на договірних умовах. Їх наймають на виконання певних видів робіт, досить часто саме тих, які мають сезонний характер. Роботодавці можуть декілька разів звертатися до них за послугами, проте жодних соціальних гарантій працівники не мають. Саме тому в умовах сьогодення для суб'єктів господарювання будівельної сфери важливо вміти не тільки знайти потрібного фахівця і повною мірою забезпечити йому всі необхідні умови, але також і утримати його.

Класичною основною метою кадрової політики є забезпечення оптимального балансу процесів відновлення та збереження кількісного і якісного складу персоналу відповідно до потреб самої організації, вимог чинного законодавства і становища на ринку праці [7]. Ця мета правильно характеризує значення кадрової політики, але сучасний підхід дав ширше поняття та переосмислив іiї значення щодо працівників. Нині вона спрямовує свої сили на створення системи управління кадрами, що грунтується здебі- 
ГАЛУЗЕВИЙ АСПЕКТ РОЗВИТКУ НАЦІОНАЛЬНОГО ГОСПОДАРСТВА

льшого не на адміністративних методах, а на економічних стимулах і соціальних гарантіях, орієнтованих на зближення інтересів працівника з інтересами організації в досягненні високої продуктивності праці, підвищенні ефективності виробництва, одержанні організацією найкращих економічних результатів [6]. Можливо, саме таке переосмислення значення кадрової політики дасть будівельній галузі краще уявлення про управління персоналом.

Зазначені причини актуалізують необхідність розроблення ефективної кадрової політики, спрямованої на формування колективу кваліфікованих працівників, забезпечення синергії їхніх інтересів з результативністю функціонування суб' єктів господарювання поряд зі збереженням високого морально-психологічного клімату (рис. 1).

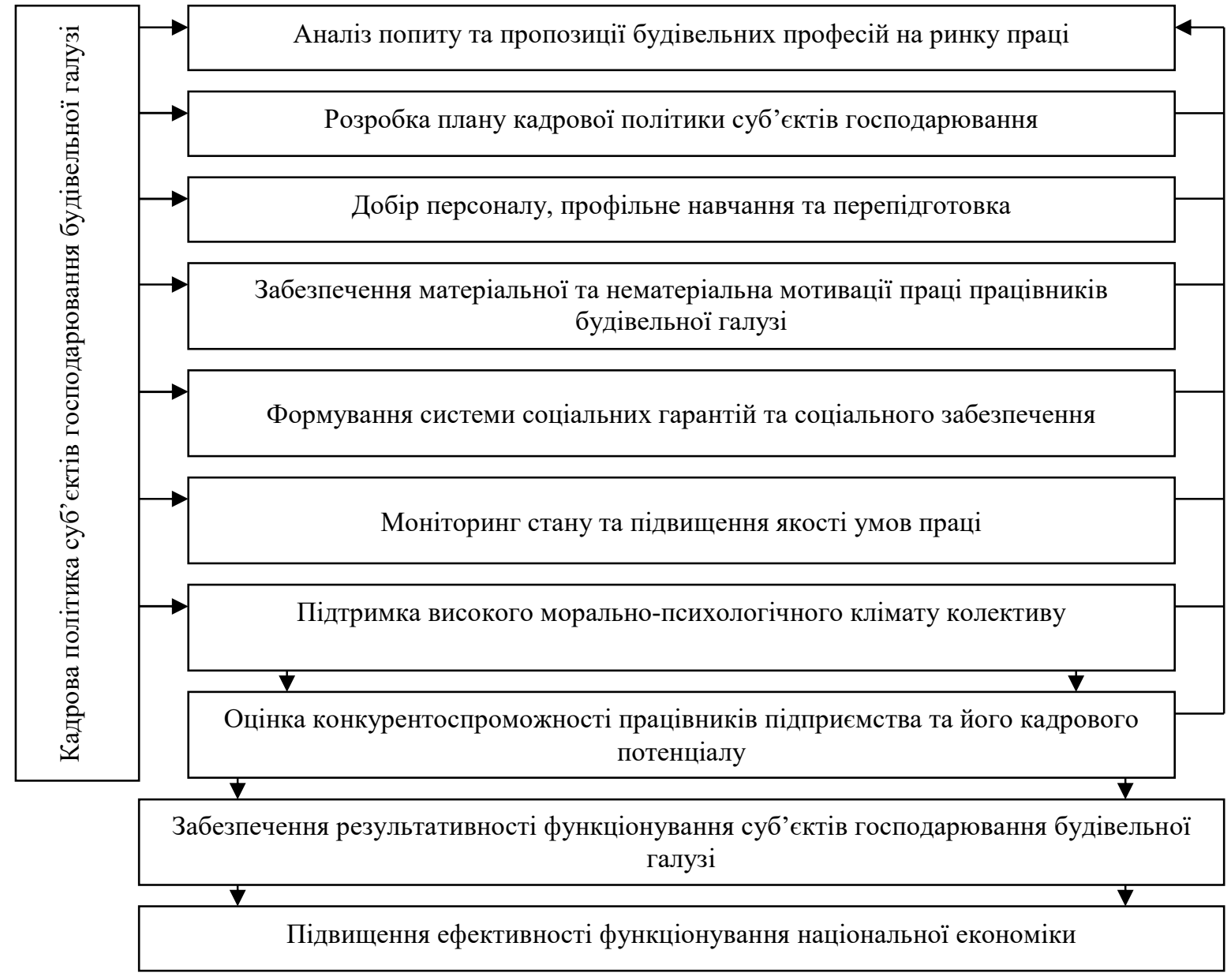

Рис. 1. Етапи розроблення кадрової політики

суб 'єктів господарювання будівельної галузі

Джерело: складено авторами.

У процесі розроблення кадрової політики суб'єкти господарювання будівельної галузі здійснюють аналіз попиту та пропозиції на ринку праці, що дозволяє провести добір відповідного персоналу та в разі необхідності здійснити його перепідготовку або спрямувати на навчання.

Важливим інструментом збереження кадрового потенціалу є забезпечення відповідного рівня матеріального та нематеріального стимулювання. Дотримання необхідного розміру заробітних плат $є$ надзвичайно важливим і важким завданням, яке постає перед підприємствами будівельної галузі. Забезпечення високого рівня матеріального та нематеріального стимулювання праці працівників може погіршувати конкурентоспроможність його товарів, робіт та послуг через їхню високу вартість, що в підсумку може 
ГАЛУЗЕВИЙ АСПЕКТ РОЗВИТКУ НАЦІОНАЛЬНОГО ГОСПОДАРСТВА

мати безпосередній вплив і на результати його фінансово-господарської діяльності. 3 іншого боку, невідповідність рівня оплати праці наявним вимогам профільних працівників спричинить їх звільнення, що, у свою чергу, унеможливить виробничі процеси на підприємстві. Враховуючи, що виробничим циклам суб'єктів господарювання будівельної галузі притаманний довготривалий характер, то їх тимчасове зупинення може призвести до ще більших фінансових збитків і матеріальних втрат.

Висновки і пропозиції. Важливими складовими кадрової політики підприємств будівельної галузі виступають також наявна система соціальних гарантій та соціального забезпечення, наявні умови праці, а також панівний морально-психологічний клімат у колективі. Приділення керівництвом підприємства відповідної уваги процесу розробки та реалізації кадрової політики на підприємстві дозволить збалансувати наявність висококваліфікованого кадрового потенціалу з високою результативністю його функціонування, що, у свою чергу, буде мати позитивний вплив на стан не лише будівельної галузі, але i створить умови для оновлення житлового фонду та розвитку національної економіки.

Проте з урахуванням стану національної економіки, рівня життя суспільства та його купівельної спроможності, забезпечення інтенсивного оновлення житлового фонду та ефективного функціонування будівельної галузі без належної державної підтримки вбачається досить сумнівним. Саме держава повинна допомогти подолати кризу в галузі та забезпечити безперервний процес інфраструктурного розвитку країни.

\section{Список використаних джерел}

1. Виноградський М. Д., Виноградська А. М., Шкапова О. М. Управління персоналом: навч. посіб. 2-ге вид. Київ: Центр учбової літератури, 2009. 502 с.

2. Державна служба статистики України: офіційний веб-сайт. URL: http://www.ukrstat.gov.ua.

3. Житловий фонд України 2018: статистичний збірник. URL: http://www.ukrstat.gov.ua.

4. Забаштанський М. М. Концесійні відносини: фінансові детермінанти розвитку в Україні: монографія. Київ: Кондор-Видавництво, 2016. 382 с.

5. Козич О. М. Державне регулювання діяльності будівельної галузі України. Публічне управління: теорія та практика. 2012. № 3(11). С. 138-142.

6. Севастьянов Р. В., Ткаченко С. А. Кадрова політика підприємства та напрями її вдосконалення. Економічний вісник Запорізької інженерної академії. 2013. С. 177-187. URL: http://www. zgia. zp.ua.

7. Хміль Ф. І. Управління персоналом. Київ: Видавничий центр «Академія», 2006. 488 с.

\section{References}

1. Vynohradskyi, M. D., Vynohradska, A. M., Shkapova, O. M. (2009). Upravlinnia personalom [Management the personnel]. Kyiv: Tsentr uchbovoi literatury [in Ukrainian].

2. Derzhavna sluzhba statystyky Ukrainy: ofitsiinyi veb-sait [The State Statistics Service of Ukraine: official website]. Retrieved from http://www.ukrstat.gov.ua.

3. Zhytlovyi fond Ukrainy 2018: statystychnyi zbirnyk [Housing Fund of Ukraine: statistical compilation] (2018). Retrieved from http://www.ukrstat.gov.ua.

4. Zabashtanskyi, M. M. (2016). Kontsesiini vidnosyny: finansovi determinanty rozvytku v Ukraini [Concessional relations: financial determinants of development in Ukraine]. Kyiv: KondorVydavnytstvo [in Ukrainian].

5. Kozych, O. M. (2012). Derzhavne rehuliuvannia diialnosti budivelnoi haluzi Ukrainy [State regulation of the construction industry in Ukraine]. Publichne upravlinnia: teoriia ta praktyka Public Administration: Theory and Practice, 3(11), 138-142 [in Ukrainian].

6. Sevastianov, R. V., Tkachenko, S. A. (2013). Kadrova polityka pidpryiemstva ta napriamy ii vdoskonalennia [Company personnel policies and areas of improvement]. Ekonomichnyi visnyk Zaporizkoi inzhenernoi akademii - Economic Bulletin Zaporozhye Engineering Academy, 177-187. Retrieved from http://www. zgia. zp.ua [in Ukrainian].

7. Khmil, F. I. (2006). Upravlinnia personalom [Management the personnel]. Kyiv: Vydavnychyi tsentr «Akademiia» [in Ukrainian]. 
ГАЛУЗЕВИЙ АСПЕКТ РОЗВИТКУ НАЦІОНАЛЬНОГО ГОСПОДАРСТВА

Забаштанський Максим Миколайович - доктор економічних наук, професор, директор Навчальнонаукового інституту бізнесу, природокористування і туризму, Чернігівський національний технологічний університет (вул. Шевченка, 95, м. Чернігів, 14035, Україна).

Забаштанский Максим Николаевич - доктор экономических наук, профессор, директор Учебно-научного института бизнеса, природопользования и туризма (ул. Шевченко, 95, г. Чернигов, 14035, Украина).

Zabashtanskyi Maksym - Doctor of Economics, Professor, Director of Educational-Scientific Institute of Business, Environtal Management and Tourism, Chernihiv National University of Technology (95 Shevchenka Str., 14035 Chernihiv, Ukraine).

E-mail: mazani@ukr.net

ORCID: http://orcid.org/0000-0001-9417-0163

ResearcherID: G-6145-2014

Роговий Андрій Віталійович - доктор економічних наук, доцент, доцент кафедри туризму, Чернігівський національний технологічний університет (вул. Шевченка, 95, м. Чернігів, 14035, Україна).

Роговой Андрей Витальевич - доктор экономических наук, доцент, доцент кафедры туризма, Черниговский национальный технологический университет (ул. Шевченко, 95, г. Чернигов, 14035, Украина).

Rogovyi Andrii - Doctor of Economics, Associate Professor, Associate Professor of Department of tourism, Chernihiv National University of Technology (95 Shevchenka Str., 14035 Chernihiv, Ukraine).

E-mail: rogovoy1976@ukr.net

ORCID: http://orcid.org/0000-0001-5445-214X

ResearcherID: F-7319-2016

Шульга Світлана Сергіївна - магістр, Чернігівський національний технологічний університет (вул. Шевченка, 95, м. Чернігів, 14035, Україна).

Шульга Светлана Сергеевна - магистр, Черниговский национальный технологический университет (ул. Шевченко, 95, г. Чернигов, 14035, Украина).

Shulha Svitlana - master student, Chernihiv National University of Technology (95 Shevchenka Str., 14035 Chernihiv, Ukraine).

E-mail: s.shulga.97@ukr.net 